\title{
SISTEM PENDUKUNG KEPUTUSAN SELEKSI TENAGA KERJA UNTUK SECURITY SERVICE MENGGUNAKAN METODE ARAS
}

\author{
Tetty Rosmaria Sitompul, Nelly Astuti Hasibuan \\ STMIK Budi Darma, Medan, Indonesia \\ Jalan Sisingamangaraja No. 338, Simp Limun, Medan, Indonesia
}

\begin{abstract}
Abstrak
PT.ISS INDONESIA merupakan perusahaa yang telah memiliki karyawan, yang sangat besar. Dengan tujuh cabang yang tersebar di Indonesia, PT.ISS INDONESIA memiliki lebih dari 500 tenaga kerja. Penerimaan tenaga kerja akan terus berlangsung sleama pembukaan swalayan atau PT.ISS INDONESIA membutuhkan tambahan karyawan untuk pengembangan atau mengisi formasi yang kosong. Subjek pada penelitian ini adalah aplikasi sistem pendukung keputusan yang digunakan untuk membantu proses seleksi karyawan yang sesuai dengan kriteria - kriteria yang ditetapkan oleh manajemen PT.ISS INDONESIA. Desain sistem dengan model proses modified waterfall mencakup definisi persyaratan yang dibutuhkan user agar dapat merancang sistem untuk pemodelan proses, pemodelan data dan user interface. Pada penelitian yang dilakukan diharapkan dapat menghasilkan perangkat lunak Sistem Pendukung Keputusan Seleksi Calon Karyawan Dengan Metode ARAS yang dapat digunakan untuk memanajemen data calon karyawan dan kriteria yang terkomputerisasi mulai dari pembobotan, perhitungan nilai dominasi, hitung preferensi, perhitungan nilai indeks dan perhitungan ARAS.
\end{abstract}

Kata kunci: Sistem Pendukun Keputusan, Seleksi Karyawan, Metode ARAS

\begin{abstract}
PT. ISS INDONESIA is a company that already has employees, which is very big. With seven branches spread across Indonesia, PT. ISS INDONESIA has more than 500 workers. Recruitment will continue as the opening of supermarkets or PT. ISS INDONESIA requires additional employees to develop or fill in empty formations. Subjects in this study are the application of decision support systems used to assist employee selection process in accordance with the criteria set by the management PT. ISS INDONESIA. System design with modified waterfall process model includes the definition of requirements required by the user in order to design the system for process modeling, data modeling, and user interface. In this research, it is expected to produce Decision Support Candidate Selection Software System With ARAS Method that can be used to manage employee candidate data and computerized criteria ranging from weighting, calculation of dominance value, arithmetic preference, calculation of index value and ARAS calculation.
\end{abstract}

Keywords: Decision Support System, Employee Selection, ARAS Method

\section{PENDAHULUAN}

PT. ISS Indonesia merupakan kelompok ISS didirikan sebagai perusahaan keamanan (scurity company) Denmark. Dalam mendapatkan sumber daya manusia yang berkualitas sesuai dengan kebutuhan perusahaan membutuhkan proses yang cukup lama. Selama ini dalam penerimaan tenaga kerja khususnya di bidang scuritysistem pengambilan keputusan terkait dengan penerimaan tenaga kerja masih secara manualdan pihak manajemen personalia PT. ISS terkadang merasa kesulitan melakukan penilaian seta mengevaluasi data tersebut secara langsung.meiihat kemampuan khusus dari calon tenaga kerja security service yang memenuhi prasyarat tertentu dalam pertemuan yang singkat adalah tugas dan tanggung jawabyang besar, karena itu diburuhkan kejelian agar tidak terjadi salah pilih calon tenaga kerja. Pertimbangan secara fisik dan akademik saja tidak cukup dalam proses penerimaan tenaga kerja yang melamar. Hal tersebut kurang efisien karena kendala yang sering ditemukan dalam proses penerimaan tenaga kerja di PT. ISS sangat tersulit dalam membuat pilihan dengan cepat dan tepatserta upaya menghilangkan faktor subjektifitas dari manajer personalia sehingga setiap pilihan yang dibuat bersifat objektif dengan berdasarkan pada kriteria-kriteria yang diharapkan oleh perusahaan.

Maka dari itu diperlukan sebuah aplikasi yang mampu mendukungnya. Untuk menghindari subjektifitas keputusan yang dihasilkan diperlukan suatu sistem pendukung keputusan (Decision Support System/DSS) yang dapat membantu manajemen personalia dalam memutuskan pelamar mana yang akan diterima.Masalah seleksi calon tenaga kerja security service dapat diatasi dengan membuat suatu sistempendukung keputusan.Untuk diterima menjadi tenaga kerja barusecurity serviceharus berdasarkan kriteria-kriteria yang ditentukan antara lain, tinggi badan, berat badan, kecakapan, usiadan ilmu bela diri[5][8]. Banyak penelitian yang dilakukan untuk menyelesaikanmasalah ini dengan menggunakan berbagai algoritma. Salah satunya adalah dengan menggunakan Metode additive ratio assessment (ARAS).

Metode additive ratio assessment (ARAS). Menurut Stanujkic dan Jovanovic, metode ARAS dikembangkan oleh Zavadskas dan Turskis pada tahun 2010. Metode ARAS merupakan salah satumetode pengambilan keputusan 
multikriteria berdasarkan pada konsepperangkingan menggunakan utility degree yaitu dengan membandingkan nilaiindeks keseluruhan setiap alternatif terhadap nilai indeks keseluruhan alternatif optimal. Pada penelitian ini, dibahas tentang metode $A R A S$ yang diterapkan padapemilihan perekrutan karyawan security service padaPT. ISS Indonesia.

Sistem Pendukung Keputusan (SPK) adalah sistem yang dapat membantu seseorang dalam mengambil keputusan yang akurat dan tepat sasaran. Banyak permasalahan yang dapat diselesaikan dengan menggunakan SPK. Sistem Pendukung Keputusan (SPK) biasanya dibangun untuk mendukung solusi atas suatu masalah atau untuk suatu peluang. Aplikasi Sistem Pendukung Keputusan (SPK) digunakan dalam pengambilan keputusan. Aplikasi Sistem Pendukung Keputusan (SPK) menggunakan CBIS (Computer Based Information systems) yang fleksibel, interaktif, dan dapat diadaptasi[1][6][7].

\section{TEORITIS}

\subsection{Sistem Pendukung Keputusan}

Sistem Pendukung Keputusan (SPK) biasanya dibangun untuk mendukung solusi atas suatu masalah atau untuk suatu peluang. Aplikasi Sistem Pendukung Keputusan (SPK) digunakan dalam pengambilan keputusan. Aplikasi Sistem Pendukung Keputusan (SPK) menggunakan CBIS (Computer Based Information systems) yang fleksibel, interaktif, dan dapat diadaptasi, yang dikembangkan untuk mendukung solusi atas masalah manajemen spesifikyang tidak terstruktur[2][3].

\subsection{Seleksi Calon Tenaga Kerja}

Dalam mencari calon tenaga kerja yang dianggap memenuhi kriteria yang sesuai dengan karakter kerja yang dilamar. Untuk mendapatkan tenaga kerja yang sesuai dengan karakter pekerjaan itu perlu perangkat alat unji yang sanggup memilah-milah diantara sekian pelamar. alat uji harus mampu memberikan gambaran objektif dan membuat suatu rekomendasi untuk menolak dan menerima calon tenaga kerja berdasarkan suatu dugaan tentang potensi-potensi dari calon tenaga kerja untuk berhasil dalam bekerja.

Dalam perencanaan sumber daya manusia, rekrutmen dan seleksi merupakan tahapan dalam rangka pengadaan. Pengadaan sumber daya manusia didasarkan pada analisis kebutuhan sumber daya manusia setiap organisasi atau unit organisasi. Wujud analisis kebutuhan sumber daya manusia dapat berupa analisis jabatan atau formasi kebutuhan pegawai.

Dengan dilakukannya penyeleksian, perusahaan mengetahui orang-orang seperti apa yang cocok dengan budaya tersebut. Misalnya perusahaan membutuhkan orang-orang yang mampuh mengambil keputusan dibawah tekanan kususnya pada perusahaan jasa dan perusahaan konsultan atau orang-orang yang dapat bekerja sama dengan baik dan kelompok dan bukan orang-orang yang individualis dan kompetitif.

\subsection{Security Service}

Security Service (Satuan Pengamanan) satuan kelompok petugas yang dibentuk oleh instansi/proyek/badan usaha untuk melakukan keamanan fisik (physical security) dalam rangka penyelenggaraan keamanan swakarsa di lingkungan kerjanya. Semua bentuk usaha atau bisnis baik yang berskala besar maupun kecil pasti membutuhkan perlindungan. Dengan adanya perlindungan perusahaan diharapkan dapat menghasilkan produk yang baik, efisien dan menguntungkan tanpa adanya gangguan dari pihak manapun yang akan merugikan perusahaan itu sendiri. Dengan demikian sistem pengamanan dan keamanan yang ada disuatu perusahaan, dalam hal ini security, tidak saja bertugas menangani masalah kriminalitas pencurian, perampokkan dan hal-hal lainnya. Tetapi untuk melakukan langkah-langkah security itu sendiri.

\subsection{Metode Additive Ratio Assessment (ARAS)}

Metode ARAS merupakan salah satu metode pengambilan keputusan multikriteria berdasarkan pada konsep perangkingan menggunakan utility degree yaitu dengan membandingkan nilai indeks keseluruhan setiap alternatif terhadap nilai indeks keseluruhan alternatif optimal.

Berikut merupakan langkah langkah dari metode ARAS[4], yaitu:

1. Menentukan matriks keputusan

Matriks keputusan disusun berdasarkan nilai dari setiap alternatif ke-iterhadap suatu kriteria ke-j yaitu

$$
X=X_{i j}, i=1,2 \ldots, m, j=1,2, \ldots, n
$$

2. Menentukan nilai optimal dari setiap kriteria $\left(X_{0 j}\right)$ 
Jika pembuat keputusan tidak mempunyai pilihan dalam menentukan nilai optimal, maka dapat ditentukan dengan

$$
X_{0 j}=\begin{aligned}
& \max _{i} x_{i j}, j i k a j \text { adalah atribut keuntungan (benefid) } \\
& \max _{i} x_{i j}, j i k a j \text { adalah atribut biaya }(\cos t)
\end{aligned}
$$

3. Menghitung matriks keputusan dengan nilai optimal ternormalisasi

Matriks keputusan yang disusun berdasarkan perbandingan berpasangan dari setiap alternatif pada suatu kriteria harus dinormalisasi menjadi skala yang dapat dibandingkan. Matriks keputusan ternormalisasi adalah $R=r_{i j}$, dengan

$$
r_{i j}=\frac{\frac{x_{i j}}{m} \text { jika } j \text { adalah atribut keuntungan (benefid) }}{\frac{x_{i j}}{m}} \text { ika } j \text { adalah atribut biaya cost }
$$

4. Menghitung matriks keputusan dengan nilai optimal ternormalisasi terbobot $(V)$ Matriks keputusan ternormalisasi terbobot dihitung dengan cara mengalikan elemen matriks keputusan ternormalisasi $\left(r_{i j}\right.$, $)$ dengan elemen bobot kriteria $\left(w_{j},\right)$. Secara matematis dapat dituliskan,

$V=v_{i j}$, dengan $v_{i j}=r_{i j} w_{j}, i=0,1 \ldots, m, j=1,2 \ldots, n$.

5. Menghitung indeks nilai secara keseluruhan setiap alternatif $\left(s_{i}\right)$

Nilai indeks keseluruhan setiap alternatif dihitung dengan cara menjumlahkan elemen matriks keputusan ternormalisasi terbobot pada setiap alternatifnya. Secara matematis dapat dituliskan,

$S_{i}=\underset{j=1^{v_{i j}, i=0,1 \ldots, m}}{n}$

Dengan $S_{i}$ adalah nilai indeks keseluruhan pada alternatif ke- $i$.

6. Menghitung utility degree dari setiap alternatif $Q_{i}$

Nilai utility degree dihitung dengan cara membagi nilai indeks keseluruhan pada alternatif ke- $i$ dengan nilai indeks keseluruhan pada alternatif yang optimal [7]. Secara matematis dapat dituliskan,

$$
Q_{i}=\frac{s_{i}}{s_{0}}, i=1,0 \ldots, m
$$

\section{ANALISA DAN PEMBAHASAN}

Dalam penelitian ini, terdapat lima calon karyawan di PT. ISS yang aka diseleksi. Data yang digunakan dalam penelitian ini adalah data yang secara acak sebanyak lima calon karwayan dari sekian banyak kandidat. Calon karyawan security disebut alternatif (A) yaitu $\mathrm{A}_{1}, \mathrm{~A}_{2}, \mathrm{~A}_{3}, \mathrm{~A}_{4}, \mathrm{~A}_{5}$. Sedangkan syarat-syarat karyawan security yang ditentukan perusahaan disebut kriteria $(\mathrm{C})$. Kriteria karyawan security yang ditentukan oleh perusahaan adalah tinggi badan $\left(\mathrm{C}_{1}\right)$, berat badan $\left(\mathrm{C}_{2}\right)$, kecakapan berkomunikasi $\left(\mathrm{C}_{3}\right)$, usia $\left(\mathrm{C}_{4}\right)$, dan Ilmu bela diri $\left(\mathrm{C}_{5}\right)$. Setiap kriteria kemudian dikonversi ke dalam suatu nilai.

Tabel 1. Kriteria tinggi badan $\left(\mathrm{C}_{1}\right)$,

\begin{tabular}{|c|c|}
\hline Tinggi badan $(\mathrm{cm})$ & Nilai kriteria \\
\hline $176-180$ & 5 \\
\hline $166-170$ & 4 \\
\hline $161-165$ & 3 \\
\hline $156-160$ & 2 \\
\hline $150-155$ & 1 \\
\hline
\end{tabular}

Tabel 2. Kriteria berat badan $\left(\mathrm{C}_{2}\right)$,

\begin{tabular}{|c|c|}
\hline Berat badan $(\mathrm{Kg})$ & Nilai kriteria \\
\hline $70-75$ & 5 \\
\hline
\end{tabular}




\begin{tabular}{|c|c|}
\hline Berat badan $(\mathrm{Kg})$ & Nilai kriteria \\
\hline $65-70$ & 4 \\
\hline $60-65$ & 3 \\
\hline $55-60$ & 2 \\
\hline $50-55$ & 1 \\
\hline
\end{tabular}

Tabel 3. Kriteria usia $\left(\mathrm{C}_{3}\right)$,

\begin{tabular}{|c|c|}
\hline Usia(tahun) & Nilai kriteria \\
\hline $20-30$ & 5 \\
\hline $30-35$ & 4 \\
\hline $36-40$ & 3 \\
\hline $17-19$ & 2 \\
\hline $41-65$ & 1 \\
\hline
\end{tabular}

Tabel 4. Kriteria beladiri $\left(\mathrm{C}_{4}\right)$,

\begin{tabular}{|c|c|}
\hline Usia(tahun) & Nilai kriteria \\
\hline $71-99$ & 5 \\
\hline $66-70$ & 4 \\
\hline $61-65$ & 3 \\
\hline $56-60$ & 2 \\
\hline $50-55$ & 1 \\
\hline
\end{tabular}

Tabel 5. Kriteria kecakapan komunikasi $\left(\mathrm{C}_{5}\right)$,

\begin{tabular}{|c|c|}
\hline Kecakapan & Nilai kriteria \\
\hline $71-99$ & 5 \\
\hline $66-70$ & 4 \\
\hline $61-65$ & 3 \\
\hline $56-60$ & 2 \\
\hline $50-55$ & 1 \\
\hline
\end{tabular}

\subsection{Matriks Perbandingan Berpasangan dan Bobot Kriteria}

Sebelum menganalisis masalah simulasi pemilihan calon security terbaik di PT. ISS diperlukan suatu nilai perbandingan berpasangan untuk menentukan tingkat kepentingan suatu kriteria terhadap kriteria lainnya. Nilai perbandingan berpasangan antar kriteria disusun berdasarkan keputusan bagian divisi security di PT. ISS. kriteria kecakapan 5 kali lebih penting dari kriteria berat, sama pentingnya dengan kriteria beladiri dan 5 kali lebih penting dari kriteria tinggi. Kriteria beladiri 4 kali lebih penting dari kriteria berat. Kriteria usia 4 kali lebih penting dari kriteria kecakapan, 5 kali lebih penting dari kriteria berat, 5 kali lebih penting dari kriteria beladiri dan 5 kali lebih penting dari kriteria tinggi. Kriteria tinggi 4 kali lebih penting dari kriteria berat dan 4 kali lebih penting dari kriteria beladiri. Maka matriks perbandingan hasil analisis preferensi gabungan untuk semua kriteria perbandingan berpasangan antar kriteria disajikan pada Tabel 6.

Tabel 6. Nilai perbandingan berpasangan

\begin{tabular}{|l|c|c|c|c|c|}
\hline Kriteria & $\begin{array}{c}\text { Kecakapan } \\
(\mathrm{c} 5)\end{array}$ & $\begin{array}{c}\text { Berat } \\
(\mathrm{c} 2)\end{array}$ & $\begin{array}{c}\text { Beladiri } \\
(\mathrm{c} 4)\end{array}$ & $\begin{array}{c}\text { Usia } \\
(\mathrm{c} 3)\end{array}$ & $\begin{array}{c}\text { Tinggi } \\
(\mathrm{c} 1)\end{array}$ \\
\hline kecakapan(c5) & 1 & 5 & 1 & $1 / 4$ & 5 \\
\hline Berat (c2) & $1 / 5$ & 1 & $1 / 4$ & $1 / 5$ & $1 / 4$ \\
\hline beladiri (c4) & 1 & 4 & 1 & $1 / 5$ & $1 / 4$ \\
\hline usia (c3) & 4 & 5 & 5 & 1 & 5 \\
\hline Tinggi (c1) & $1 / 5$ & 4 & 4 & $1 / 5$ & 1 \\
\hline
\end{tabular}

Tabel 7. Matriks Faktor Pembobotan Hirarki untuk Semua Kriteria yang Disederhanakan 


\begin{tabular}{|l|c|c|c|c|c|}
\hline Kriteria & $\begin{array}{c}\text { Kecakapan } \\
(\mathrm{c} 5)\end{array}$ & $\begin{array}{c}\text { Berat } \\
(\mathrm{c} 2)\end{array}$ & $\begin{array}{c}\text { Beladiri } \\
(\mathrm{c} 4)\end{array}$ & $\begin{array}{c}\text { Usia } \\
(\mathrm{c} 3)\end{array}$ & $\begin{array}{c}\text { Tinggi } \\
(\mathrm{c} 1)\end{array}$ \\
\hline kecakapan(c5) & 1,000 & 5,000 & 1,000 & 0,250 & 5,000 \\
\hline Berat (c2) & 0,200 & 1,000 & 0,250 & 0,200 & 0,250 \\
\hline beladiri (c4) & 1,000 & 4,000 & 1,000 & 0,200 & 0,250 \\
\hline Usia (c3) & 4,000 & 5,000 & 5,000 & 1,000 & 5,000 \\
\hline Tinggi (c1) & 0,200 & 4,000 & 4,000 & 0,200 & 1,000 \\
\hline$\Sigma$ & 6,400 & 19,00 & 11,25 & 1,850 & 11,50 \\
\hline
\end{tabular}

Dengan unsur-unsur pada tiap kolom dibagi dengan jumlah kolom yang bersangkutan, akan diperoleh bobot relatif yang dinormalkan. Nilai vektor eigen dihasilkan dari rata-rata bobot relatif untuk setiap baris. Hasilnya dapat pada tabel berikut ini:

Tabel 8. Matriks Faktor Pembobotan Hirarki untuk Semua Kriteria yang Dinormalkan

\begin{tabular}{|l|c|c|c|c|c|c|}
\hline Kriteria & $\begin{array}{c}\text { Kecakapan } \\
(\mathrm{c5})\end{array}$ & $\begin{array}{c}\text { Berat } \\
(\mathrm{c} 2)\end{array}$ & $\begin{array}{c}\text { Beladiri } \\
(\mathrm{c} 4)\end{array}$ & $\begin{array}{c}\text { Usia } \\
(\mathrm{c} 3)\end{array}$ & $\begin{array}{c}\text { Tinggi } \\
(\mathrm{c} 1)\end{array}$ & $\begin{array}{c}\text { Vektor } \\
\text { eigen }\end{array}$ \\
\hline kecakapan(c5) & 0,156 & 0,263 & 0,088 & 0,135 & 0,128 & 0,154 \\
\hline Berat (c2) & 0,031 & 0,052 & 0,021 & 0,108 & 0,128 & 0,068 \\
\hline Beladiri (c4) & 0,156 & 0,210 & 0,088 & 0,108 & 0,102 & 0,095 \\
\hline Usia (c3) & 0,625 & 0,263 & 0,444 & 0,540 & 0,512 & 0,379 \\
\hline Tinggi (c1) & 0,031 & 0,210 & 0,355 & 0,108 & 0,102 & 0,123 \\
\hline
\end{tabular}

Selanjutnya nilai eigen maksimum $\left(\boldsymbol{\lambda}_{\text {maksimum }}\right)$ diperoleh dengan menjumlahkan hasil perkalian jumlah kolom dengan vektor eigen. Nilai eigen maksimum yang dapat diperoleh adalah:

$\left(\boldsymbol{\lambda}_{\text {maksimum }}\right)=(6,400 \times 0,514)+(19,00 \times 0,068)+(11,25 \times 0,019)+(1,850 \times 0,379)+(11,50 \times 0,123)=5,462$

\subsection{Tingkat Konsistensi}

Untuk menguji apakah matriks perbandingan berpasangan konsisten, dilakukan perhitungan berdasarkan Afshari et al. [1] dengan langkah sebagai berikut.

1. Menghitung matriks jumlah terbobot $(B)$ dengan cara mengalikan matriks perbandingan berpasangan $(A)$ dengan bobot kriteria $(W)$.

$$
\begin{aligned}
& \mathrm{B}=b_{j} \text { dengan } b_{j}={ }_{j=1}^{5} a_{h j} w_{j}, h=1,2,3 \ldots, . .5 \\
& \mathrm{~B}_{1}=(1 \times 0,497)+(1 \times 0,168)+(3 \times 0,126)+(3 \times 0,126)+(5 \times 0,080)=1,821 \\
& \mathrm{~B}_{2}=(1 \times 0,497)+(1 \times 0,168)+(0,333 \times 0,126)+(0,333 \times 0,126)+(0,2 \times 0,080)=0,764
\end{aligned}
$$

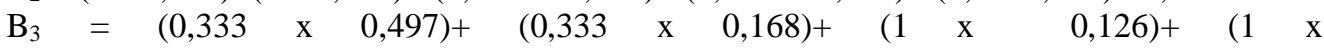

$$
\begin{aligned}
& +(0,333 \times 0,080)=0,500
\end{aligned}
$$

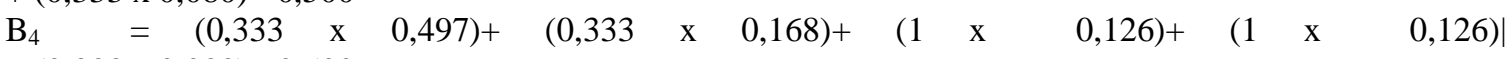

$$
\begin{aligned}
& +(0,333 \times 0,080)=0,500 \\
& \mathrm{~B}_{5}=(0,2 \quad \mathrm{x} \quad 0,497)+\quad(0,2 \quad \mathrm{x} \quad 0,168)+\quad(0,333 \quad \mathrm{x} \quad 0,126)+\quad(0,333 \quad \mathrm{x} \\
& +(1 \times 0,080)=0,296
\end{aligned}
$$

2. Membagi semua elemen matriks jumlah terbobot dengan masing-masing elemen bobot kriteria.

$$
\begin{aligned}
& \mathrm{C}=C_{j} \text { dengan } C_{j}=\frac{B_{j}}{W_{j}}, A=1,2,3 \ldots 5 \\
& C_{1}=\frac{(1,821 * 1)+(0,764 * 1)+(0,500 * 3)+(0,500 * 3)+(0,296 * 5)}{(0,497 * 1)+(0,168 * 1)+(0,126 * 3)+(0,126 * 3)+(0,080 * 5)}=3,879 \\
& C_{2}=\frac{(1,821 * 1)+(0,764 * 1)+(0,500 * 0,333)+(0,500 * 0,333)+(0,296 * 0,2)}{(0,497 * 1)+(0,168 * 1)+(0,126 * 0,333)+(0,126 * 0,333)+(0,080 * 0,2)}=3,892 \\
& C_{3}=\frac{(1,821 * 0,333)+(0,764 * 0,333)+(0,500 * 1)+(0,500 * 1)+(0,296 * 0,333)}{(0,497 * 0,333)+(0,168 * 0,333)+(0,126 * 1)+(0,126 * 1)+(0,080 * 0,333)}=3,918 \\
& C_{4}=\frac{(1,821 * 0,333)+(0,764 * 0,333)+(0,500 * 1)+(0,500 * 1)+(0,296 * 0,333)}{(0,497 * 0,333)+(0,168 * 0,333)+(0,126 * 1)+(0,126 * 1)+(0,080 * 0,333)}=3,918 \\
& C_{5}=\frac{(1,821 * 0,2)+(0,764 * 0,2)+(0,500 * 0,333)+(0,500 * 0,333)+(0,296 * 1)}{(0,497 * 0,2)+(0,168 * 0,2)+(0,126 * 0,333)+(0,126 * 0,333)+(0,080 * 1)}=3,871
\end{aligned}
$$


3. Menghitung menggunakan persamaan (2.3).

$$
\lambda \max =\frac{3,879+3,892+3,918+3,918+3,871}{5}=3,895
$$

4. Menentukan indeks konsistensi ( $C I)$ menggunakan persamaan (2.4).

$$
C I=\frac{3,895-5}{5-1}=0,276
$$

5. Menghitung rasio konsistensi $(C R)$ menggunakan persamaan (2.5).

$$
C R=\frac{0,276}{1,12}=0,246
$$

Karena nilai rasio konsistensi $(C R)=0,0246<0,1$ maka matriks perbandingan berpasangan antar kriteria konsisten. Perhitungan $C R$ dan kekonsistenannya dapat diselesaikan dengan program berikut.

\subsection{Penerapan Additive Ratio Assessment (ARAS)}

Setelah matriks perbandingan antar kriteria konsisten selanjutnya dilakukan proses perangkingan menggunakan metode ARAS.

1. Menentukan matriks keputusan $\mathrm{x}$.

Tabel 9. Matriks keputusan dengan nilai optimal

\begin{tabular}{|l|c|c|c|c|c|}
\hline \multirow{2}{*}{ NAMA } & \multicolumn{5}{|c|}{ Kriteria (Bobot) } \\
\cline { 2 - 6 } & C1 & C2 & C3 & C4 & C5 \\
\hline Fran & 3 & 3 & 3 & 4 & 4 \\
\hline Ardi & 4 & 4 & 5 & 3 & 3 \\
\hline Ciko & 2 & 3 & 4 & 5 & 5 \\
\hline Agus & 5 & 5 & 4 & 3 & 3 \\
\hline Ono & 3 & 3 & 5 & 4 & 4 \\
\hline
\end{tabular}

Penentuan nilai optimal untuk setiap kriteria menggunakan tipe tujuan dari masing-masing kriteria.

a. Tinggi

Penilaian dari kriteria tinggi badan dimulai dari lebih rendah hingga lebih tinggi. Suatu alternatif security akan semakin baik jika mempunyai tinggi yang optimal sehingga digunakan tipe tujuan maksimisasi.

b. Berat

Penilaian dari kriteria bedan badan dimulai darilebih ringan ke berat. Suatu alternatif security akan semakin baik jika mempunyai berat bobot yang ideal sehingga digunakan tipe tujuan maksimisasi.

c. Usia

Penilaian dari kriteria usia dimulai dari yang tertua hingga termuda. Suatu alternatif security akan semakin baik jika berumur 20-30 tahun sehingga digunakan tipe tujuan maksimisasi.

d. Beladiri

Penilaian dari kriteria beladiri dimulai dari singkatnya jangka beladiri hingga lamanya jangka beladiri. Suatu alternatif security akan semakin baik jika memiliki ilmu beladirinya sehingga digunakan tipe tujuan maksimisasi.

e. Kecakapan

Penilaian dari kriteria kecakapan dimulai dari tata bahasa yang baik. Suatu alternatif security akan semakin baik tata bahasa yang tidak baik hingga ke tata bahasa yang sangat baik sehingga digunakan tipe tujuan maksimisasi.

Semua kriteria yang digunakan pada pemilihan security terbaik mempunyai tipe tujuan maksimisasi.

2. Menghitung matriks keputusan dengan nilai optimal ternormalisasi

$$
R=r_{i j}
$$

Karena semua kriteria mempunyai tipe tujuan maksimisasi, berdasarkan persamaan (1) maka

$r_{i j}=\frac{x_{i j}}{5}{ }_{i=0} x_{i j}=1,2, \ldots 5$

$X_{1}=\sqrt{3^{2}+4^{2}+2^{2}+5^{2}+3^{2}}=\sqrt{63}=7,937$

$r_{11}=\frac{x_{11}}{x_{1}}=\frac{3}{7,937}=0,377$

$r_{12}=\frac{x_{12}}{x_{1}}=\frac{4}{7,937}=0,504$

$r_{13}=\frac{x_{13}}{x_{1}}=\frac{2}{7,937}=0,252$

$r_{14}=\frac{x_{14}}{x_{1}}=\frac{5}{7,937}=0,629$

Tetty Rosmaria Sitompul | http://ejurnal.stmik-budidarma.ac.id/index.php/mib | Page | 6 


$$
\begin{aligned}
& r_{15}=\frac{x_{15}}{x_{1}}=\frac{3}{7,937}=0,377 \\
& C_{2}=\sqrt{3^{2}+4^{2}+3^{2}+5^{2}+3^{2}}=\sqrt{68}=7,615 \\
& r_{11}=\frac{x_{11}}{x_{2}}=\frac{3}{8,246}=0,363 \\
& r_{12}=\frac{x_{12}}{x_{2}}=\frac{4}{8,246}=0,485 \\
& r_{13}=\frac{x_{13}}{x_{2}}=\frac{3}{8,246}=0,364 \\
& r_{14}=\frac{x_{14}}{x_{2}}=\frac{5}{8,246}=0,606 \\
& r_{15}=\frac{x_{15}}{x_{2}}=\frac{3}{8,246}=0,363 \\
& C_{3}=\sqrt{3^{2}+5^{2}+4^{2}+4^{2}+5^{2}}=\sqrt{91}=9,539 \\
& r_{11}=\frac{x_{11}}{x_{3}}=\frac{3}{9,539}=0,314 \\
& r_{12}=\frac{x_{12}}{x_{3}}=\frac{5}{9,539}=0,524 \\
& r_{13}=\frac{x_{13}}{x_{3}}=\frac{4}{9,539}=0,419 \\
& r_{14}=\frac{x_{14}}{x_{3}}=\frac{4}{9,539}=0,419 \\
& r_{15}=\frac{x_{15}}{x_{3}}=\frac{5}{9,539}=0,524 \\
& C_{4}=\sqrt{4^{2}+3^{2}+5^{2}+3^{2}+4^{2}}=\sqrt{75}=8,660 \\
& r_{11}=\frac{x_{11}}{x_{4}}=\frac{4}{8,660}=0,461 \\
& r_{12}=\frac{x_{12}}{x_{4}}=\frac{3}{8,660}=0,346 \\
& r_{13}=\frac{x_{13}}{x_{4}}=\frac{5}{8,660}=0,577 \\
& r_{14}=\frac{x_{14}}{x_{4}}=\frac{3}{8,660}=0,346 \\
& r_{15}=\frac{x_{15}}{x_{4}}=\frac{4}{8,660}=0,461 \\
& C_{5}=\sqrt{4^{2}+3^{2}+5^{2}+3^{2}+4^{2}}=\sqrt{75}=8,660 \\
& r_{11}=\frac{x_{11}}{x_{5}}=\frac{4}{8,660}=0,461 \\
& r_{12}=\frac{x_{12}}{x_{5}}=\frac{3}{8,660}=0,346 \\
& r_{13}=\frac{x_{13}}{x_{5}}=\frac{5}{8,660}=0,577 \\
& r_{14}=\frac{x_{14}}{x_{5}}=\frac{3}{8,660}=0,346 \\
& r_{15}=\frac{x_{15}}{x_{5}}=\frac{4}{8,660}=0,461
\end{aligned}
$$

Dari perhitungan tersebut diperoleh matriks keputusan dengan nilai optimal ternormalisasi yang disajikan pada Tabel 10.

Tabel 10. Matriks keputusan dengan nilai optimal ternormalisasi

\begin{tabular}{|l|c|c|c|c|c|}
\hline \multirow{2}{*}{ NAMA } & \multicolumn{5}{|c|}{ KRITERIA } \\
\cline { 2 - 6 } & $\mathrm{C} 1$ & $\mathrm{C} 2$ & $\mathrm{C} 3$ & $\mathrm{C} 4$ & $\mathrm{C} 5$ \\
\hline Fran & 0,377 & 0,363 & 0,314 & 0,461 & 0,461 \\
\hline Ardi & 0,504 & 0,485 & 0,524 & 0,346 & 0,346 \\
\hline Ciko & 0,252 & 0,363 & 0,419 & 0,577 & 0,577 \\
\hline Agus & 0,629 & 0,606 & 0,419 & 0,346 & 0,346 \\
\hline Ono & 0,377 & 0,363 & 0,524 & 0,461 & 0,461 \\
\hline
\end{tabular}

3. Menghitung matriks keputusan dengan nilai optimal ternormalisasi terbobot $\mathrm{V}=\mathrm{v}_{\mathrm{ij}}$

$$
\begin{array}{lc}
v_{i j}=r_{i j} \cdot w_{i}, i=1,2 \ldots .5, j=1,2 \ldots 5 \\
\mathrm{~V}_{1}=0,377 * 0,497 & 0,363 * 0,168
\end{array}
$$

$$
0,314 * 0,126 \quad 0,461 * 0,126
$$


MEDIA INFORMATIKA BUDIDARMA, Vol 2, No 1, Januari 2018

ISSN 2614-5278 (media cetak)

ISSN 2548-8368 (media online)

Hal 1-9

$$
\begin{array}{rlrlrl}
\mathrm{V}_{2}= & 0,504 * 0,497 & 0,485 * 0,168 & 0,524 * 0,126 & 0,346 * 0,126 & 0,346 * 0,080 \\
& 0,629 * 0,497 \\
\mathrm{~V}_{3}= & 0,252 * 0,497 & 0,363 * 0,168 & 0,419 * 0,126 & 0,577 * 0,126 & 0,577 * 0,0800, \\
& 378 * 0,497 & & & \\
\mathrm{~V}_{4}= & 0,629 * 0,497 & 0,606 * 0,168 & 0,419 * 0,126 & 0,346 * 0,126 & 0,346 * 0,080 \\
& 0,504 * 0,497 \\
\mathrm{~V}_{5}= & 0,377 * 0,497 & 0,363 * 0,168 & 0,524 * 0,126 & 0,461 * 0,126 & 0,461 * 0,080 \\
& 0,378 * 0,497 & & & &
\end{array}
$$

Tabel 11. Matriks keputusan dengan nilai optimal ternormalisasi terbobot

\begin{tabular}{|l|c|c|c|c|c|}
\hline \multirow{2}{*}{ NAMA } & \multicolumn{5}{|c|}{ Kriteria } \\
\cline { 2 - 6 } & $\mathrm{C} 1$ & $\mathrm{C} 2$ & $\mathrm{C} 3$ & $\mathrm{C} 4$ & $\mathrm{C} 5$ \\
\hline Fran & 0,187 & 0,061 & 0,039 & 0,058 & 0,036 \\
\hline Ardi & 0,250 & 0,081 & 0,066 & 0,043 & 0,027 \\
\hline Ciko & 0,125 & 0,061 & 0,052 & 0,072 & 0,046 \\
\hline Agus & 0,312 & 0,101 & 0,052 & 0,043 & 0,027 \\
\hline Ono & 0,187 & 0,061 & 0,066 & 0,058 & 0,036 \\
\hline
\end{tabular}

4. Menghitung nilai indeks secara keseluruhan setiap alternatif $\left(\mathrm{S}_{1}\right)$

$$
S_{i}=\stackrel{5}{j=1}, v_{i j,} i=0,1 \ldots 5
$$

Perhitungan nilai indeks secara keseluruhan setiap alternatif diselesaikan Dengan

$$
\begin{aligned}
& S_{1}=\frac{0,187+0,061+0,039+0,058+0,036}{1}=0,381 \\
& S_{2}=\frac{0,25+0,081+0,066+0,043+0,027}{1}=0,467 \\
& S_{3}=\frac{0,125+0,061+0,052+0,072+0,046}{1}=0,356 \\
& S_{4}=\frac{0,312+0,101+0,052+0,0430+, 027}{1}=0,535 \\
& S_{5}=\frac{0,187+0,061+0,066+0,058+0,036}{1}=0,408
\end{aligned}
$$

Dari program tersebut diperoleh rangking dan nilai utility degree yang disajikan pada Tabel

Tabel 12. Matriks keputusan dengan nilai optimal ternormalisasi terbobot

\begin{tabular}{|l|c|c|c|c|c|c|}
\hline \multirow{2}{*}{ NAMA } & \multicolumn{5}{|c|}{ Kriteria } & \multirow{2}{*}{ Nilai } \\
\cline { 2 - 6 } & C1 & C2 & C3 & C4 & C5 & \\
\hline Fran & 0,187 & 0,061 & 0,039 & 0,058 & 0,036 & 0,381 \\
\hline Ardi & 0,250 & 0,081 & 0,066 & 0,043 & 0,027 & 0,467 \\
\hline Ciko & 0,125 & 0,061 & 0,052 & 0,072 & 0,046 & 0,356 \\
\hline Agus & 0,312 & 0,101 & 0,052 & 0,043 & 0,027 & 0,535 \\
\hline Ono & 0,187 & 0,061 & 0,066 & 0,058 & 0,036 & 0,408 \\
\hline
\end{tabular}

5. Merangking security

Perangkingan security dilakukan dengan cara menghitung utility degree dari setiap alternatif $\left(\mathrm{Q}_{\mathrm{i}}\right)$, yaitu dengan membagi nilai indeks secara keseluruhan setiap alternatif dengan nilai indeks secara keseluruhan alternatif yang optimal.

$$
Q_{i}=\frac{s_{i}}{s_{0}}, i=1,2 \ldots 5
$$

Tetty Rosmaria Sitompul | http://ejurnal.stmik-budidarma.ac.id/index.php/mib | Page | 8 
Diperoleh rangking dan nilai utility degree yang disajikan pada tabel 13.

Tabel 12. Rangking dan nilai utility degree
\begin{tabular}{|c|c|l|}
\hline Rangking & $\mathrm{Q}_{\mathrm{i}}$ & Nama \\
\hline 1 & 0,535 & Agus \\
\hline 2 & 0,467 & Ardi \\
\hline 3 & 0,408 & Ono \\
\hline 4 & 0,381 & Frans \\
\hline 5 & 0,356 & ciko \\
\hline
\end{tabular}

6. Penentuan security terbaik

Berdasarkan Tabel 12, security pertama (Agus) merupakan security terbaik karena mempunyai utility degree terbesar yaitu 0,544. Artinya bahwa tingkat kepuasan security pertama (Agus) sangat baik sehingga security tersebut akan lebih utama untuk dipilih dan cenderung untuk dipertahankan.

\section{KESIMPULAN}

Setelah melalui tahap pengujian pada sistem pendukung keputusan penerimaan calon tenaga kerja security service, di dapatkan kesimpulan bahwa:

1. Proses seleksi tenaga kerja security yang dilakukan oleh PT. ISS hahrus memenuhi beberapa kriteria yang ditentukan oleh pihak perusahaan.

2. Dengan menerapkan metode Aras dalam penyeleksian calon tenaga kerja security dapat membantu personalia dalam menentukan calon pekerja yang diterima dengan cepat dan tepat.

3. Aplikasi sistem pendukung keputusan penyeleksian calon tenaga kerja security menggunakan metode aras telah selesai dirancang dan dapat dijadikan salah satu alternatif dalam mengambil keputusan penyeleksian calon tenaga kerja

\section{REFERENCES}

[1] Mesran, G. Ginting, Suginam, and R. Rahim, "Implementation of Elimination and Choice Expressing Reality ( ELECTRE ) Method in Selecting the Best Lecturer ( Case Study STMIK BUDI DARMA ),” Int. J. Eng. Res. Technol. (IJERT, vol. 6, no. 2, pp. 141-144, 2017.

[2] Kusrini, Konsep dan Aplikasi Sistem Pendukung Keputusan. Yogyakarta: Andi, 2007.

[3] S. Kusumadewi, S. Hartati, A. Harjoko, and R. Wardoyo, Fuzzy Multi-Attribute Decision Making (Fuzzy MADM). Yogyakarta: Graha Ilmu, 2006.

[4] Esra; and AyĢegül, "AIR CONDITIONER SELECTION PROBLEM WITH COPRAS AND ARAS METHODS," Manas J. Soc. Stud., vol. 5 , no. 2,2016

[5] G.-H. Tzeng and J.-J. Huang, Multiple Attribute Decision Making Method And Applications. CRC Press, 2011.

[6] P. Sianturi, M. Mesran, P. Ramadhani, and N. W. Al-Hafiz, "SISTEM PENDUKUNG KEPUTUSAN PENENTUAN PENERIMA BANTUAN OPERASIONAL PENYELENGARAAN ( BOP ) PAUD ( PENDIDIKAN ANAK USIA DINI ) MENERAPKAN METODE ELECTRE ( STUDI KASUS : DINAS PENDIDIKAN KABUPATEN SIMALUNGUN )," KOMIK (Konferensi Nas. Teknol. Inf. dan Komputer), vol. I, no. 1, pp. 20-26, 2017.

[7] H. Nurdiyanto and Heryanita Meilia, "SISTEM PENDUKUNG KEPUTUSAN PENENTUAN PRIORITAS PENGEMBANGAN INDUSTRI KECIL DAN MENENGAH DI LAMPUNG TENGAH MENGGUNAKAN ANALITICAL HIERARCHY PROCESS (AHP)," in Seminar Nasional Teknologi Informasi dan Multimedia 2016, 2016, no. February, pp. 1-7.

[8] M. Mesran, S. Suginam, S. D. Nasution, and A. P. U. Siahaan, "PENERAPAN WEIGHTED SUM MODEL ( WSM ) DALAM PENENTUAN PESERTA JAMINAN,” J. Ris. Sist. Inf. dan Tek. Inform., vol. 2, no. 1, pp. 40-47, 2017. 